\title{
PHYSICO-CHEMICAL CHARACTERIZATION OF IGALO BAY PELOID (MONTENEGRO) AND ASSESSMENT OF THE POLLUTION OF POTENTIALLY TOXIC ELEMENTS IN THE SAMPLING AREA
}

\author{
MILJAN BIGOVIC $^{1 *}$, MILOVAN ROGANOVIC $^{2}$, IVANA MILASEVIC $^{3}$, DIJANA DJUROVIC $^{3}$, \\ VJEROSLAVA SLAVIC ${ }^{4}$, MILICA KOSOVIC ${ }^{5}$, MIA VLAHOVIC ${ }^{5}$, SVETLANA PEROVIC $^{1}$, \\ ANDREJ PEROVIC ${ }^{1}$, VLATKO KASTRATOVIC ${ }^{1}$, ZORICA POTPARA $^{2}$, MILICA MARTINOVIC ${ }^{2}$, \\ SNEZANA PANTOVIC ${ }^{2}$
}

\author{
${ }^{1}$ University of Montenegro, Faculty of Natural Sciences and Mathematics, G. Washington Boulevard, 81000, Podgorica, Montenegro \\ ${ }^{2}$ University of Montenegro, Faculty of Medicine, Kruševac, 81000, Podgorica, Montenegro \\ ${ }^{3}$ Institute for Public Health of Montenegro, Ljubljanskaa, 81000, Podgorica, Montenegro \\ ${ }^{4}$ Institute "Dr Simo Milosevic” Igalo, 5 Sava Ilica, 85347, Igalo, Herceg Novi, Montenegro \\ ${ }^{5}$ University of Montenegro, Faculty for Technology and Metallurgy, G. Washington Boulevard, 81000, Podgorica, Montenegro
}

*corresponding author: miljan@ucg.ac.me

\begin{abstract}
Igalo (Montenegro) is known for a number of natural therapeutic factors (sea peloid, mineral water, sand and salt), is close to the sea and is extremely valuable. Peloid from Igalo is known as a resort of healing, cosmetic or aesthetic application. Also, there are studies of medical application and biological activity of some other peloids, which are directly related to their chemical composition. In this paper we analysed the content of light and potentially toxic elements as well as the most important non-metals present in the composition of peloid and listed their main and well-known biological roles. The chemical composition of the Igalo peloid was compared with several peloids from the region (Croatia, Italy, Spain), as well as the chemical composition of peloids obtained from the Dead Sea, because these peloids showed an extraordinary therapeutic potential and they are already used for medical purposes (spa centres, balneotherapy etc.). Also, we have determined some environmental indicators based on the data of the content of metals. The obtained value means that there is no potentially toxic element pollution in the sediment.
\end{abstract}

\section{Rezumat}

Igalo (Muntenegru) este cunoscut pentru o serie de factori terapeutici naturali (peloidul marin, apa minerală, nisip, sare). În această lucrare, am analizat conţinutul în elemente potențial toxice, precum şi nemetalele mai importante prezente în compoziția peloidelor. Compoziția chimică a Igalopeloidului a fost comparată cu cu a altora (Croația, Italia, Spania), precum și cu cele din Marea Moartă, deoarece acestea prezintă un potențial terapeutic şi sunt folosite în scopuri medicale. De asemenea, am stabilit indicatori de mediu pe baza datelor privind conținutul în metale. Valoarea obținută reflectă lipsa elementelor în sediment.

Keywords: peloid, Igalo, toxic elements, pollution

\section{Introduction}

Owing to the finding of marine peloids with therapeutic properties, the Bay of Herceg Novi is recognized in the Balkan region and beyond. The Institute for Physical Medicine, Rehabilitation and Rheumatology "Dr Simo Milošević", known for the use of peloids for medical and cosmetic purposes, is located on the shore of this part of the bay [1]. The Igalo peloid is created in an ambient where salt water and fresh water are mixed under the hydrodynamic impact of the water mass, resulting in the re-sedimentation of the carbonate flysch, rich in lime and silt.

The peloid extends from the mouth of the Sutorina River to Njivice settlement, at 42 degrees and 28 minutes north latitude and 18 degrees and 32 minutes eastern longitude.

The presence of various organic and inorganic substances is necessary for the development of many biological processes. When it comes to inorganic substances, water is one of the main factors, but content of metals [2] have great importance as well. According to the influence that chemical elements can have on the human organism, they are divided into essential, useful and toxic (which is highly dependent on their concentration).

Essential and useful elements are required by humans in different concentrations (which is in direct connection to the chemical nature of element), and they are divided into macrominerals $(\mathrm{Na}, \mathrm{K}, \mathrm{Mg}, \mathrm{Ca}, \mathrm{Cl})$, trace 
FARMACIA, 2020, Vol. 68, 3

elements ( $\mathrm{Fe}, \mathrm{Zn}, \mathrm{Cu}$ ) and microelements ( $\mathrm{Se}, \mathrm{Si}, \mathrm{I}, \mathrm{F}$, As, Mn, Mo, Co, Cr, V, Ni, Li) [3].

The quantity of elements in sea water is large, especially given the volume thereof. According to many authors, all natural elements of the Periodic system can be found in sea water (for example, sea water has about 550,000 tons of holmium, while its quantity is five times smaller on the land [4]).

The most important roles of metals in biological processes are: structural role (construction of structures, skeletons, stabilization of nucleic acids), transferring the charge (concentration gradient through the membranes, transmission of electrical impulses through neurons, function, metabolism and degradation of organic molecules).

Some of these metals are present in the body in high concentrations (such as sodium, potassium, calcium, magnesium), while others are necessary in significantly smaller quantities (iron, zinc, cobalt, copper). 25 elements are necessary for the normal functioning of the human organism and the maintenance of homeostasis [3]. According to the International Society of Medical Hydrology, "Peloid is a natural product consisting of a mixture of sea, salt lake or minero-medicinal water (liquid phase), with organic and inorganic material (solid phase) produced by biological action and geological action". Apart from this, a new definition of peloid was proposed by Gomez and associates: "Peloid is a maturated mud or muddy dispersion with healing and/or cosmetic properties, composed of a complex mixture of fine-grained natural materials of geologic and/or biologic origin, mineral water or seawater and commonly organic compounds from biological metabolic activity" $[5,6]$.

Peloid is mud found at the coast in Igalo with therapeutic and cosmetic properties. Also, it is well known that muds are frequently used in pharmacy, spas and aesthetic medicine [7]. Thus far, no studies on the chemical composition of Igalo peloid have been carried out, nor have its potential medicinal roperties been examined. According to the majority of publications, the chemical composition is the main factor upon which the final characteristics and hence the use of peloids depend (organic and inorganic substances constituting the peloid).

In our research, we determined the physical and chemical characteristics of peloid from Igalo (the peeling temperature at the sampling site, $\mathrm{pH}$-value, density, electrical conductivity, the content of light and heavy metals, the content of some non-metals and amount of water). Subsequently, we compared the chemical composition of peloids from Igalo with the properties of some geological materials which have already been used for cosmetic or therapeutic purposes, or at least with such potential. There are a lot of studies that confirm therapeutic effects of peloids. Peloid therapy is effective in providing improvement in pain relief, function, daily life activities, and quality of life in patients suffering from chronic lateral epicondylitis [8]; it has effects on levels of cortisol [9]; it is suggested to use peloid as a supplementary therapeutic agent in carpal tunnel syndrome [10] etc. Researches in Russia prepared intravaginal gel from Dead Sea peloid for treating luteal-phase defect [11].

Afterwards, we have determined some environmental indicators based on the data of the content of metals such as: contamination factor (CF), pollution load index (PLI) and index of geoaccumulation ( $\left.\mathrm{I}_{\text {geo }}\right)$. These three indexes can provide important information about the level of pollution by a particular potentially toxic element, the amount of toxic element that is accumulated on a certain sampled surface as well as the total level of pollution by potentially toxic elements [12].

\section{Materials and Methods}

The analysed samples were collected from four spots, all distant one kilometre away from the place where the Sutorina River flows into the sea, the supply site of the Igalo Institute. The peloid was extracted from a boat, using a special shovel designed for those purposes, in the shallow sea $(2 \mathrm{~m})$. Whole collected material was deposited into special concrete basins where it was soaked with sea water and homogenized until a certain consistency was achieved.

The temperature was measured in situ, while the $\mathrm{pH}$ value, conductivity of each sample and density were measured in a laboratory (the sample is immediately sealed after collecting, in order to avoid any contamination with external substances).

In order to determine minerals and metals content, we prepared the samples using the microwave digestion system (Microwave Reaction System-Anton Paar). The samples were prepared in line with the digging instructions for sediments and soil proposed by the manufacturer (Laboratory Procedure Book Anton Paar, 2009) in the following manner: $0.2 \mathrm{~g}$ of sample were treated with a mixture of concentrated nitric acid ( 5 $\mathrm{mL})$, concentrated hydrofluoric acid $(2 \mathrm{~mL})$ and concentrated solution of hydrogen-peroxide $(2 \mathrm{~mL})$. After cooling, the boric acid $(0.8 \mathrm{~g})$ and water $(15 \mathrm{~mL})$ were added to the mixture. The resulting mixture was subjected to digestion once again.

The elements' content in the sample (metals and nonmetals) was determined by means of the induced plasma emission spectrometer (ICP-OES), branded by Spectro Arcos. The content of mercury was determined by Direct Mercury Analyser DMA-80, produced by Milestone. All work standards were prepared from certified standard solutions obtained from the Sigma Aldrich Company, with initial concentrations $1000 \mathrm{mg} / \mathrm{dm}^{3}$.

The water content was determined first by drying up to $80^{\circ} \mathrm{C}$ during 24 hours, and then by gravimetric analysis techniques. 
The percentage of nitrogen was determined by Kjeldahl method (Instrument K-350 Distilation Unit, K-436 Speeddigester, K-415 Duoscrub).

$\mathrm{pH}$ values were measured by means of $\mathrm{pH}$-meter $\mathrm{HI}$ 221 Hanna Instruments.

Conductivity was determined by means of Digital conductometer Hanna Instruments.

\section{Results and Discussion}

Physical properties

The salinity of the water in the Adriatic Sea is $38 \%$ $39 \%$ [13]. Basic physical parameters of the Igalo peloid are shown in Table I.

Given the fact that the $\mathrm{pH}$ value and the electrical conductivity could not be determined directly from the peloid sample, a $1 \%$ aqueous solution was made with a view to measuring these constants. Measurements were performed at a temperature of $25^{\circ} \mathrm{C}$.
Table I

Basic physical characteristics of the Igalo peloid

\begin{tabular}{|l|c|c|}
\hline \multicolumn{1}{|c|}{ Physical parameter } & Unit & Value \\
\hline Temperature & ${ }^{\circ} \mathrm{C}$ & 37 \\
\hline pH-value & - & 6.23 \\
\hline Density & $\mathrm{g} / \mathrm{cm}^{3}$ & 1.63 \\
\hline $\begin{array}{l}\text { Density of dry peloid (after } \\
\text { lyophilisation) }\end{array}$ & $\mathrm{g} / \mathrm{cm}^{3}$ & 0.73 \\
\hline Conductivity & $\mu \mathrm{S}$ & 134 \\
\hline
\end{tabular}

As can be concluded from the measured data, the peloid is close to neutral, with extremely poor conductivity.

\section{Chemical composition}

By chemical composition, peloid is a complex mixture of inorganic and organic compounds. In our research we were mainly interested in the inorganic composition, i.e. the concentration of metals and non-metals that compose the peloid.

The dominant elementary composition of the Igalo peloid is shown in Table II.

Table II

Inorganic chemical composition of the Igalo peloid

\begin{tabular}{|c|c|c|c|c|}
\hline Element & Symbol & Content & Unit & Detection limit (LD, mg/kg) \\
\hline Lithium & $\mathrm{Li}$ & 163.3 & $\mathrm{mg} / \mathrm{kg}$ & 0.5 \\
\hline Sodium & $\mathrm{Na}$ & 11.94 & $\mathrm{~g} / \mathrm{kg}$ & 0.5 \\
\hline Potassium & $\mathrm{K}$ & 17.76 & $\mathrm{~g} / \mathrm{kg}$ & 0.5 \\
\hline Beryllium & $\mathrm{Be}$ & 0.9 & $\mathrm{mg} / \mathrm{kg}$ & 0.1 \\
\hline Magnesium & $\mathrm{Mg}$ & 21.01 & $\mathrm{~g} / \mathrm{kg}$ & 0.5 \\
\hline Calcium & $\mathrm{Ca}$ & 53.67 & $\mathrm{~g} / \mathrm{kg}$ & 0.5 \\
\hline Strontium & $\mathrm{Sr}$ & 152.9 & $\mathrm{mg} / \mathrm{kg}$ & 0.1 \\
\hline Barium & $\mathrm{Ba}$ & 196.5 & $\mathrm{mg} / \mathrm{kg}$ & 0.1 \\
\hline Aluminium & $\mathrm{Al}$ & 67.08 & $\mathrm{~g} / \mathrm{kg}$ & 0.2 \\
\hline Gallium & $\mathrm{Ga}$ & $<0.1$ & $\mathrm{mg} / \mathrm{kg}$ & 0.1 \\
\hline Indium & In & $<0.1$ & $\mathrm{mg} / \mathrm{kg}$ & 0.1 \\
\hline Thallium & $\mathrm{Tl}$ & $<0.1$ & $\mathrm{mg} / \mathrm{kg}$ & 0.1 \\
\hline Silicon & $\mathrm{Si}$ & 120.2 & $\mathrm{~g} / \mathrm{kg}$ & 0,2 \\
\hline Tin & $\mathrm{Sn}$ & $<0.5$ & $\mathrm{mg} / \mathrm{kg}$ & 0.5 \\
\hline Lead & $\mathrm{Pb}$ & $<0.5$ & $\mathrm{mg} / \mathrm{kg}$ & 0.5 \\
\hline Arsenic & As & 5.6 & $\mathrm{mg} / \mathrm{kg}$ & 0.05 \\
\hline Antimony & $\mathrm{Sb}$ & $<0.5$ & $\mathrm{mg} / \mathrm{kg}$ & 0.5 \\
\hline Bismuth & $\mathrm{Bi}$ & $<0.1$ & $\mathrm{mg} / \mathrm{kg}$ & 0.1 \\
\hline Selenium & $\mathrm{Se}$ & $<0.5$ & $\mathrm{mg} / \mathrm{kg}$ & 0.5 \\
\hline Scandium & Sc & 14.6 & $\mathrm{mg} / \mathrm{kg}$ & 0.1 \\
\hline Yttrium & $\mathrm{Y}$ & 26.5 & $\mathrm{mg} / \mathrm{kg}$ & 0.1 \\
\hline Titanium & $\mathrm{Ti}$ & 7.61 & $\mathrm{~g} / \mathrm{kg}$ & 0.2 \\
\hline Zirconium & $\mathrm{Zr}$ & 48.0 & $\mathrm{mg} / \mathrm{kg}$ & 0.1 \\
\hline Vanadium & $\mathrm{V}$ & 92.4 & $\mathrm{mg} / \mathrm{kg}$ & 0.1 \\
\hline Chromium & $\mathrm{Cr}$ & 202.3 & $\mathrm{mg} / \mathrm{kg}$ & 0.2 \\
\hline Molybdenum & Mo & 15.1 & $\mathrm{mg} / \mathrm{kg}$ & 0.1 \\
\hline Manganese & $\mathrm{Mn}$ & 455.2 & $\mathrm{mg} / \mathrm{kg}$ & 0.1 \\
\hline Iron & $\mathrm{Fe}$ & 40.62 & $\mathrm{~g} / \mathrm{kg}$ & 0.3 \\
\hline Cobalt & $\mathrm{Co}$ & 15.7 & $\mathrm{mg} / \mathrm{kg}$ & 0.1 \\
\hline Nickel & $\mathrm{Ni}$ & 138.7 & $\mathrm{mg} / \mathrm{kg}$ & 0.2 \\
\hline Copper & $\mathrm{Cu}$ & 51.8 & $\mathrm{mg} / \mathrm{kg}$ & 0.2 \\
\hline Silver & $\mathrm{Ag}$ & $<0.1$ & $\mathrm{mg} / \mathrm{kg}$ & 0.1 \\
\hline Gold & $\mathrm{Au}$ & $<0.1$ & $\mathrm{mg} / \mathrm{kg}$ & 0.1 \\
\hline Zinc & $\mathrm{Zn}$ & 78.5 & $\mathrm{mg} / \mathrm{kg}$ & 0.1 \\
\hline Cadmium & $\mathrm{Cd}$ & $<0.01$ & $\mathrm{mg} / \mathrm{kg}$ & 0.01 \\
\hline Mercury & $\mathrm{Hg}$ & 0.11 & $\mathrm{mg} / \mathrm{kg}$ & 0.1 \\
\hline
\end{tabular}


FARMACIA, 2020, Vol. 68, 3

\begin{tabular}{|l|c|c|c|c|}
\hline \multicolumn{1}{|c|}{ Element } & Symbol & Content & Unit & Detection limit (LD, mg/kg) \\
\hline Lanthanum & $\mathrm{La}$ & 28.0 & $\mathrm{mg} / \mathrm{kg}$ & 0.1 \\
\hline Erbium & $\mathrm{Er}$ & $<0.1$ & $\mathrm{mg} / \mathrm{kg}$ & 0.1 \\
\hline Ytterbium & $\mathrm{Yb}$ & $<0.1$ & $\mathrm{mg} / \mathrm{kg}$ & 0.1 \\
\hline \multicolumn{5}{|l}{} \\
\hline Nitrogen & $\mathrm{N}$ & 0.094 & $\%$ & 0.5 \\
\hline Phosphorus & $\mathrm{P}$ & 0.678 & $\mathrm{~g} / \mathrm{kg}$ & 0.5 \\
\hline Sulphur & $\mathrm{S}$ & 6.5 & $\mathrm{~g} / \mathrm{kg}$ & Gravimetric analysis. \\
\hline \multicolumn{5}{|l}{}
\end{tabular}

Since the method for determining the concentration of most heavy metals is the induced plasma emission spectrometer (ICP-OES) with optical detector, we did not have the ability to determine some metals (e.g. As, $\mathrm{Cr}, \mathrm{Mn}$ ) in the specific oxidation state; the application of such a device gave us a total sum of all the oxidation states of the given element. The content of mercury (total, in the form of organic and inorganic species) was determined directly on the instrument for determining mercury.

Considering the fact that the most of determined metals and non-metals found in larger quantities in the soil are actually in the form of oxides, we recalculated their percentage composition in the sample of peloids in the form of oxides, as shown in Table III.

Table III

Recalculated quantities of some elements of the Igalo peloid in the form of oxides

\begin{tabular}{|l|c|c|c|}
\hline Oxide & $\begin{array}{c}\text { Oxide content } \\
(\%)\end{array}$ & $\begin{array}{c}\text { Metal content } \\
(\%)\end{array}$ & $\begin{array}{c}\text { Metal content } \\
\text { (g/kg peloid) }\end{array}$ \\
\hline $\mathrm{Al}_{2} \mathrm{O}_{3}$ & 12.7 & 6.7 & 67.1 \\
\hline $\mathrm{Fe}_{2} \mathrm{O}_{3}$ & 5.8 & 4.1 & 40.6 \\
\hline $\mathrm{MnO}$ & 0.06 & 0.046 & 0.46 \\
\hline $\mathrm{TiO}_{2}$ & 1.3 & 0.8 & 7.6 \\
\hline $\mathrm{SiO}_{2}$ & 25.72 & 12.02 & 120.2 \\
\hline
\end{tabular}

For further examination of the chemical properties of our peloid, we compared its chemical composition with the: Makirina Bay peloid mud (Croatia, [12]), Dead Sea (Near East, divided between Israel and Jordan [14]), "Cappeta" (Lucarnia Area, Italy, [15]) and Lo Pagan Lagoon (Spain, [16]). Makirina Bay peloid mud is used for local inhabitants and tourists as mud wraps, mud samples from $\mathrm{N}$ basin of the Dead Sea are used in spa hotel clinic for therapy, the mud of "Cappetta" in sulphur thermal centres and Lo Pagan natural muddy lagoon sediment is used in Spanish spas.

The content of major elements of the Igalo peloid and compared materials are presented in Table IV.

Comparison of the Igalo peloid potentially toxic element contents with other peloids is presented in Figure 1.

Table IV

Comparison of the Igalo peloid chemical composition with the composition of other peloids

\begin{tabular}{|c|c|c|c|c|c|}
\hline Element & $\begin{array}{l}\text { Igalopeloid } \\
\text { (mg/kg) }\end{array}$ & $\begin{array}{c}\text { Makirina Bay peloid } \\
(\mathrm{mg} / \mathrm{kg})\end{array}$ & $\begin{array}{c}\text { N Dead Sea Mud } \\
(\mathrm{mg} / \mathrm{kg})\end{array}$ & $\begin{array}{l}\text { The mud from "Cappetta" } \\
\text { (mg/kg) }\end{array}$ & $\begin{array}{c}\text { Lo Pagan Lagoon } \\
\text { sediments } \\
\text { (mg/kg) } \\
\end{array}$ \\
\hline $\mathbf{S i}$ & 120200 & 127182 & 139355 & 208163 & 86527 \\
\hline Al & 67080 & 43250 & 44520 & 62510 & 18950 \\
\hline $\mathbf{F e}$ & 40620 & 22650 & 29710 & 37400 & 12020 \\
\hline Mn & 455.2 & 20.0 & 46.0 & 46.0 & 14.0 \\
\hline Mg & 21010 & 30960 & 25100 & 17160 & 24360 \\
\hline $\mathbf{C a}$ & 53670 & 113100 & 147250 & 101200 & 189190 \\
\hline $\mathbf{N a}$ & 11940 & 24480 & 6600 & 5270 & 32200 \\
\hline $\mathbf{K}$ & 17760 & 12360 & 9120 & 16500 & 9100 \\
\hline Ti & 7610 & 2640 & 4740 & 3480 & 1310 \\
\hline $\mathbf{P}$ & 678.0 & 350.0 & & 700.0 & \\
\hline As & 5.6 & 14.5 & & 3.9 & 6.4 \\
\hline Cd & $<0.1$ & 0.27 & 81.0 & 0.11 & $<0.1$ \\
\hline Co & 15.7 & 7.1 & 25.0 & & 4.0 \\
\hline $\mathrm{Cr}$ & 202.3 & 82.1 & & & 42.3 \\
\hline $\mathbf{C u}$ & 51.8 & 27.6 & 2.0 & 23.0 & 24.7 \\
\hline Mo & 15.1 & 13.8 & & & 3.1 \\
\hline $\mathbf{N i}$ & 138.7 & 26.5 & & 63.0 & 20.0 \\
\hline $\mathbf{P b}$ & $<0.5$ & 23.7 & 108.0 & 8.2 & 37.5 \\
\hline $\mathbf{V}$ & 92.4 & 80.2 & 250.0 & & 41.8 \\
\hline Zn & 78.5 & 47.7 & 72.0 & 65.0 & 85.9 \\
\hline S (\%) & 0.65 & 1.45 & & & 2.37 \\
\hline
\end{tabular}

Empty spaces - the results of the given analyses are not available 
FARMACIA, 2020, Vol. 68, 3

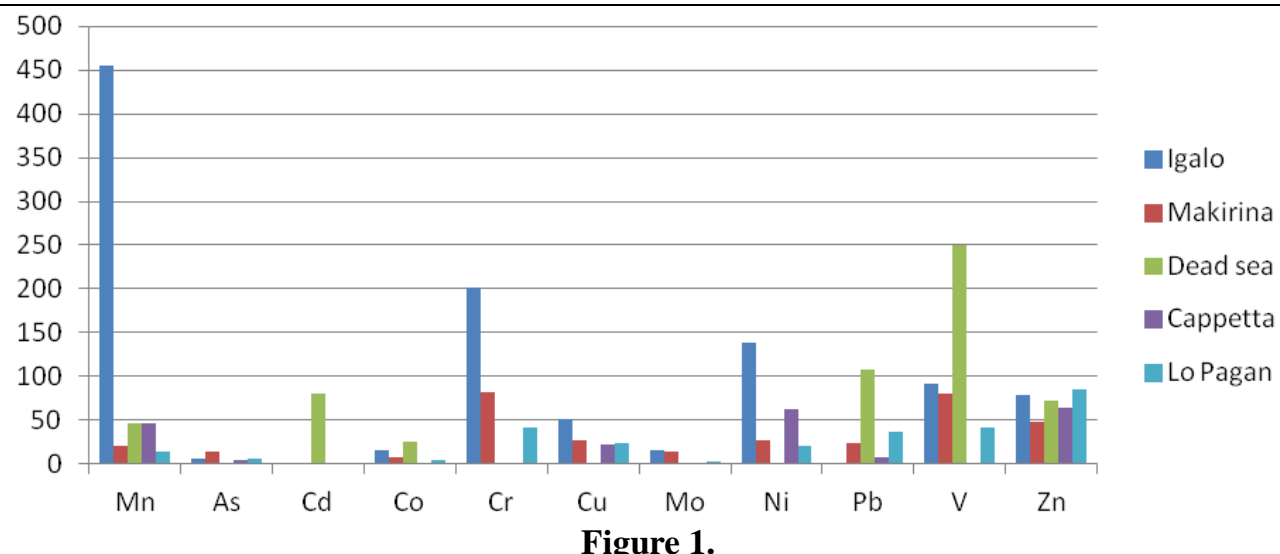

Graphic comparison of the Igalo peloid chemical composition with the composition of other peloids

Some of the major biological functions of the elements found in the Igalo peloid in large quantities [17-20] are cited below.

As is evident from the table and diagram, the content of manganese is far greater in the peloid from Igalo than from the other four locations. As manganese can occur in a large number of oxidation states $(+2,+3$, $+4,+6,+7)$, and participate in redox reactions, its coordination power is reduced and it easily releases already bound ligands (and oxygen). In biological systems, it behaves very similarly to $\mathrm{Mg}^{2+}$ - ion. Therefore, it can be bound in the enzymes instead of magnesium. Manganese is pumped out of the cytoplasm off all eukaryotic cells. Its binding interactions with proteins are very weak and therefore cannot be found in higher concentrations in the cytoplasm [17]. Manganese participates as an actor of some enzymes involved in the bio-synthesis of saccharides and cholesterol. $\mathrm{Mn}^{2+}$ ions are also included in the so-called FUR system (Iron uptake regulatory protein), which is very important system included in the relationship between uptake and growth. Manganese is also closely related to the following processes: functions of thylakoids and mitochondria and process of glucosylation [21]. It is a cofactor of numerous enzymes that remove oxygen free radicals. Deficiency of manganese leads to skeletal and cartilage defects, depressed male reproductive function, while the excess of this element may cause psychiatric disorders (memory, speech, hallucinations). The total amount of manganese in the human organism is estimated at around $12 \mathrm{mg}$. The majority of manganese is accumulated in bones, followed by the hypophysis, the mammary glands, the liver and the pancreas. The daily oral dose of manganese is $4-10 \mathrm{mg}$, depending on the taken food. There are evidences that manganese has protective effects against oxidative injury of cultured skin fibroblasts induced by UVA, dithranol and hydrogen peroxide [22].

Besides, Igalo peloid contains larger amounts of chromium. Chromium in the form of chromate or dichromate $\left(\mathrm{CrO}_{4}^{-}\right.$and $\left.\mathrm{Cr}_{2} \mathrm{O}_{7}{ }^{2-}\right)$ is very toxic, while it is non-toxic for the environment and humans in the form of $\mathrm{Cr}^{3+}$ ion. High chromatic toxicity is explained by their resemblance to sulphates and the ability to easily pass through the cell membrane. The iodide test for qualitative proving of chromium in the +6 state was negative, so on the basis of this experiment we concluded that chromium in the peloid is present in its trivalent form. Diluted chromates in the soil are translated into chromium(III) and this form that cannot be used by plants. In this way, the food chain is protected against excessive chromium [23]. The organism needs chromium in order to use glucose. It amounts to 1 - $2 \mathrm{mg}$ in the human body, but it can sometimes reach up to $12 \mathrm{mg}$. In circulation, a small portion of chromium binds to transferrin or chromoduline, while the majority is bound to the complex glucose tolerance factor (GTF). Studies have shown that insulin is inactive without the presence of chromium [24]. In cases of exposure to chromium, prolonged allergic reactions, dermatitis and conjunctivitis may occur, while chronic exposure leads to gastrointestinal problems, hepatitis and lung cancer. $\mathrm{Cr}^{3+}$ can be linked to phosphate groups from DNA. Daily chromium III requirements amount to 15 - $100 \mu \mathrm{g}$; $\mathrm{Cr}(\mathrm{VI})$ concentrations were reported as $20 \mathrm{mg} / \mathrm{L}$, with an estimated dose rate of $0.57 \mathrm{mg} / \mathrm{kg}$-day [25].

A significant amount of nickel was found in the peloid. The total amount of nickel in the human organism is around $15 \mu \mathrm{g}$, while the daily needs for this element are around $5 \mu \mathrm{g}$ [18]. Total diet studies indicate a total average oral intake of $200-300 \mu \mathrm{g} /$ day [26]. Recovery studies indicate an absorption rate of less than $15 \%$ from the gastrointestinal tract [27]. Organic substances such as oil absorb nickel very well. As a cofactor, it enters as an integral part of four important enzymatic groups: urease (hydrolytically breaks the urea), hydrogenase (oxidize hydrogen to hydronium ions), CO-dehydrogenase (oxidation of carbonmonoxide to carbon-dioxide) and methyl-coenzyme $M$ reductase (transforming the methyl group into methane [28]). Deficiency of nickel leads to growth depression, impaired reproduction and prenatal mortality 
(in animals) while the excess of this element can cause lung cancer. Moreover, nickel may replace other transition metals in their sites. Because of its electronegativity, nickel has the ability to create complexes with other organic molecules, especially iron and manganese. This can explain the side effects of low nickel in the organism leading to disturbance of metabolism of iron as well as the structure and role of the cell membrane.

The presence of vanadium and copper in Igalo peloid is evident as well. Vanadium has a relatively limited role in biological systems. The human body contains around $0.1 \mathrm{mg}$ of vanadium, while daily vanadium requirements amount to than $4 \mu \mathrm{g}$. Only $0.5 \%$ of vanadium from food is absorbed in the body and most of it is rapidly excreted. It is not accumulated in any of the organs in the body. The lack of vanadium may cause growth depression and reproduction failure. As well as chromium, vanadium plays a role in glucose metabolism (vanadium sulphate improves control of diabetes in patients with type 2 diabetes). Vanadium compounds increase the effect of insulin by stimulating phosphorylation of insulin receptor. However, due to their high toxicity, vanadium compounds are not used for therapeutic purposes [29]. Vanadate anion is structurally similar to the phosphate anion and affects the activity of ATP-ase and related enzymes and is an inhibitor of some enzymes such as alkaline phosphate. Moreover, vanadium regulates the enzyme which controls the functions of sodium in the body. Natural sources of vanadium are marine organisms and liver.

The human body contains around $2.3 \mathrm{~g}$ of zinc, while daily zinc requirements amount are 2 - $3 \mathrm{mg}$ [18]. Zinc is the only metal that has representatives in each enzyme group. The lack of this metal is directly related to low sperm concentration. There are more than 200 enzymes containing zinc. They are involved in the regulation of growth, development of the organism, fertility; they are important for the digestion, immunity and synthesis of nucleic acids. Zinc is involved in the transcription and translation processes of the genes [29]. On the other hand, in high concentrations zinc can be toxic: it can cause vomiting, abdominal pain, diarrhoea and fever [18]. Skin is the third most zincabundant tissue in humans [30]. There is evidence that zinc-deficiency $(\mathrm{ZnD})$ can cause several skin diseases: necrolytic migratory erythema [31], pellagra [32], biotin deficiency [33] and alopecia areata [34], but also $\mathrm{ZnD}$ is reported in some inflammatory diseases such as atopic dermatitis [35] and Behcet's disease [36]. There are a lot of clinical studies that confirm efficiency of zinc in wound healing [37].

Although not found in high concentrations, the content of copper in Igalo peloid is higher than in other samples collected for the purpose of comparison. The human body contains around $150 \mathrm{mg}$ of copper, while daily copper requirements amount to 1 - $2 \mathrm{mg}$ [18].
It can be found in the liver, muscles and bones. A disturbance of copper concentration in the brain and liver leads to Wilson's disease - copper is precipitated, what causes disorders of liver function, dementia and death. Copper is involved in the functioning of a large number of enzymes, of which many are involved in the transfer of electrons, the activation of oxygen and other small molecules (nitrogen, methane, carbon monoxide). There are more than ten copper dependent proteins and they have a number of important functions: production of energy in the cell, destruction of free radicals, participation in the synthesis of melanin, absorption of iron, synthesis of nitric oxide (NO). Copper is a component of oxidative enzymes involved in haem synthesis. The deficiency of copper increases the amount of cholesterol and blood pressure, anaemia, ataxia, defective melanin production and keratinization. Sea food and meat in general are very rich in copper. The human body contains around $1-2 \mathrm{mg}$ of cobalt. The main form it enters into the body is through vitamin $B_{12}$ [39]. Moreover, cobalt is involved in the synthesis of haemoglobin. The necessary daily amounts of this element are around $1 \mathrm{mg}$. A part of the cobalt that is not bound to vitamin $B_{12}$ is inaccessible for the organism and passes without changes. Deficiency of cobalt leads to anaemia, anorexia, growth depression, liver disease. The excess of this element can cause heart failure and hypothyroidism.

The human body contains around $5 \mathrm{mg}$ of molybdenum, while daily molybdenum requirements are about 0.05 $\mathrm{mg}$. This metal can be found in bones, skin and liver. About 20 enzymes contain this metal as a cofactor. One of the most important enzymes is xanthine-oxidase which participates in the synthesis of uric acid. It is important to mention the sulphite-oxygenase, which converts toxic sulphite into non-poisonous sulphate [40]. Moreover, aldehyde oxidase, the enzyme that converts aldehydes into carboxylic acids, requires the presence of molybdenum. This metal interferes with copper absorption. Molibdenum compounds are absorbed when ingested and rapidly appear in blood. Deficiency of molybdenum causes growth depression, defective keratinization while the excess of this element may cause anaemia and persistent dysentery.

The mercury concentration is slightly above the lower limit of detection, but certainly not negligible since it is one of the most toxic elements, while the arsenic is found in small quantities in comparasion with some other toxic elements. Lead and cadmium were not detected during the analysis of the Igalo peloid (within the detection limits of the instrument). It is important to note that the zinc content is comparable with the content of this metal in the other peloids, taken for comparison.

Figure 2 represents a pie-chart diagram indicating the potentially toxic element ratio in the Igalo peloid. 
FARMACIA, 2020, Vol. 68, 3

Comparison of the other metals presented in larger shown in Figure 3. quantities of the Igalo peloid and nearby peloids is

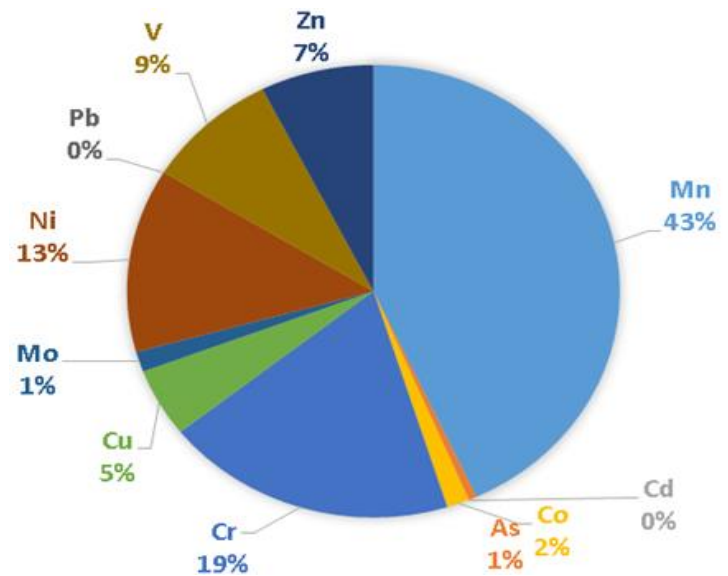

Figure 2.

The ratio of potentially toxic element concentrations in the peloid

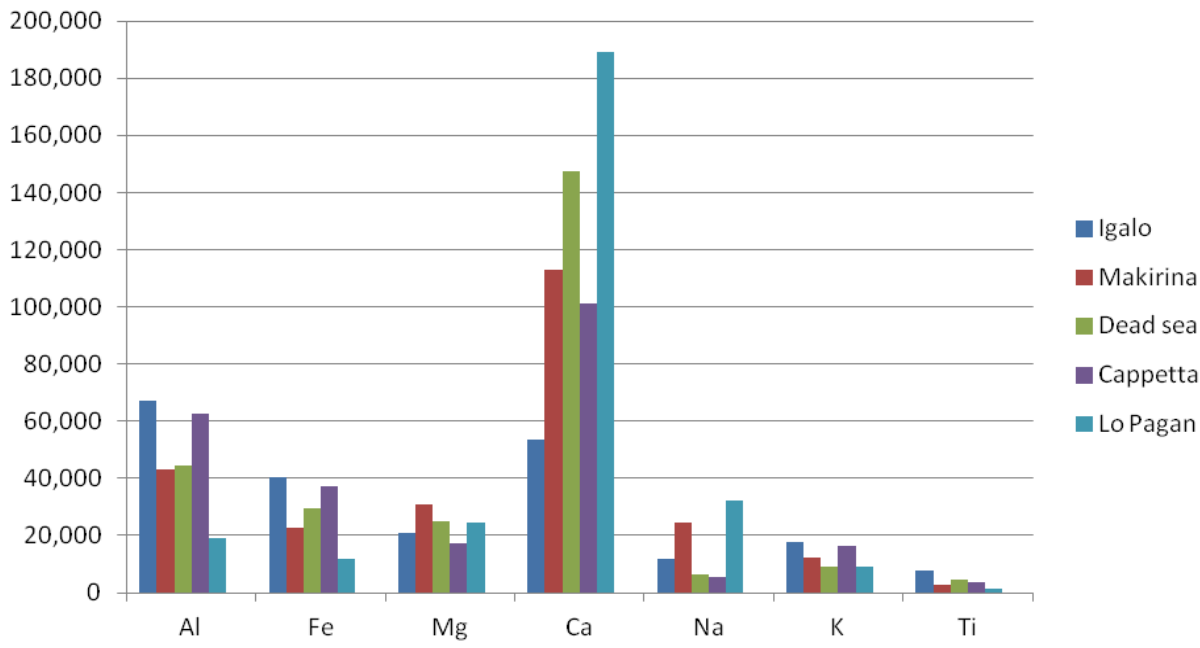

Figure 3.

The ratio of higher-concentrations of metals in the Igalo peloid

It can be noted that the Igalo peloid is rich in $\mathrm{Al}$, $\mathrm{Ca}, \mathrm{Fe}$ and $\mathrm{Mg}$ contents. The concentrations of sodium and potassium are lower.

Aluminium is implicated in the dialysis encephalopathies and in Alzheimer's disease. The human body contains around $60 \mathrm{mg}$ of aluminium. Around $5 \mathrm{mg}$ of aluminium per day taken in through food in organism, but its absorption is significantly lower - less than $10 \mu \mathrm{g}$ per day [18]. No animal species requiring aluminium as an essential element has been detected so far. Aluminium passes through the intestine and is not absorbed in the body - it is absorbed in small amounts; but no skin absorption is possible, however pulmonary absorption is. If it comes to the bloodstream, the body hardly excretes it [17].

Calcium makes about $2 \%(1-2 \mathrm{~kg})$ of the human mass and it is mostly incorporated into the bones and teeth. A small portion of calcium plays an important role in the complex mechanism of cell signal transmission and response. It participates in processes such as regulation of cell function, muscle contraction, blood clotting and enzymatic regulation; controls the release of hormones and participates in the construction of endo- and exo-skeletons. Daily calcium requirements amount to about $1 \mathrm{~g}$, depending on the sex and age (children in development and pregnant women require higher amounts of calcium [41]). Calcium has a major role in regulating epidermal functions, including cell proliferation, terminal differentiation, and cell-tocell adhesion. Aberrations in calcium regulation have been noted in psoriasis [42] and calcium is described as potential central regulator in wound healing in the skin [43].

Iron alloyed with various proteins performs a number of impressive functions vital for survival, replication and cell differentiation. One of the most important biological functions of iron is that, as a part of the haemoglobin, oxygen is transmitted to each cell in 
the body. Also, iron is present as a part of enzymes of respiratory chain, enzymes that work on DNA synthesis, free radical protection systems, and enzymes that allow cells to release energy using glucose [44]. The human body contains around $4 \mathrm{~g}$ of iron, while daily iron requirements amount to $10 \mathrm{mg}$. The lack of iron causes anaemia, while the excess of iron can damage the liver and kidneys in some cases. Some recent studies described the involvement of iron in wound healing: patients with severe diabetic foot ulcerations have iron deficiency [45]. Also, chronic inflammatory conditions such as rheumatoid arthritis (RA) and Lupus Erythematosus are associated with dysregulation of local cutaneous iron haemostasis [46]. Iron ions form many complexes, and some studies have shown that chelate iron compounds protect the skin from radiation and are added to sunscreen preparations with the aim to protect [47].

Magnesium is the most common divalent metal in the cell. The largest part of this metal is tied in bones, and while the rest is tied in the ATP and in the cell. One of the most important roles of magnesium is in phosphate metabolism. Out of the total of ten glycolic enzymes, as many as five contain magnesium [48]. Additionally, it regulates transport through the cell membrane and participates in protein synthesis. The human body contains around $25 \mathrm{~g}$ of magnesium, while daily requirements amount for this element are the most $200 \mathrm{mg}$.

Sodium and potassium are transported through the cell membrane - sodium is an intracellular and potassium is an extracellular metal. As the membrane is not permeable to hydrated ions, the transport of these two metals is carried out via ion channels and pumps for sodium and potassium. This transport is very important for maintaining the ionic potential of the cell [49]. The human body contains around $130 \mathrm{~g}$ of potassium and $100 \mathrm{~g}$ of sodium. The quantity of sodium and potassium that a person takes in through food is different from culture to culture and from person to person - it is around $1-6 \mathrm{~g}$ for potassium and $2-9 \mathrm{~g}$ for sodium. However, daily recommended doses are $3 \mathrm{~g}$ for potassium and also $3 \mathrm{~g}$ for sodium, too [18]. Sodium is important for the regulation of osmotic pressure, the dissolution of proteins and organic acids. The lack of sodium leads to muscle twitching, but in the case of excess sodium, it comes to interference in the heart and kidneys. It may cause an increase in blood pressure as well. Potassium has several roles: regulation of intercellular fluids, solubility of proteins, work of nerve impulses and muscle contractions. The lack of potassium in males can lead to irregular

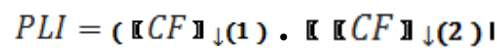

If the value of PLI index is less than 1 , there is no potentially toxic element pollution in the sediment, but if the index is higher than 1 , the pollution exists. contraction (arrhythmia), while excess of potassium affects the excitability of the nervous system.

There is growing interest in scientific researches evaluating the efficacy and safety of using dietary supplements containing silicon. Its use aims at increasing blood levels of this element and improving the skin and its annexes appearance [50]. It was shown that silicon can stimulate fibroblasts to secrete collagen type I [51].

\section{Environmental parameters}

The presence of potentially toxic elements and their concentration are very important parameters of the environmental state and indicators of its pollution.

As we have stated in the introduction, in our study we determined the following three parameters: the contamination factor (CF), the pollution load index (PLI) and the index of geoaccumulation $\left(\mathrm{I}_{\text {geo }}\right)$.

Contamination factor $(C F)$ describes the contamination of a given potentially toxic element in an investigated area [52]. We count it by using the following equation:

$$
\mathrm{CF}=\mathrm{Cs} / \mathrm{Cb} \text {, }
$$

where $\mathrm{C}_{\mathrm{s}}$ represents the content of potentially toxic element in the sample, while $C_{b}$ represents the potentially toxic element background value (so far, we do not have reliable experimental data that this value is applicable to skin exposure).

$\mathrm{CF}$ factor is classified into four categories: low contamination $(\mathrm{CF}<1)$; moderate contamination $(1<\mathrm{CF}<3)$; considerable contamination $(3<\mathrm{CF}<6)$ and very high contamination $(\mathrm{CF}>6)$.

Index of geoaccumulation $\left(I_{\text {geo }}\right)$ is used for the evaluation of the potentially toxic element contamination of peloid mud [53]. This index is expressed as:

$$
I_{\text {geo }}=\log _{2}\left(C_{n} / 1.5 B_{n}\right) \text {, }
$$

where $C_{n}$ represents the measured content of potentially toxic element, while $B_{n}$ represents the geochemical background value for potentially toxic element.

Because of possible variations of the back-ground data due the lithological variations, a factor of 1.5 is used.

$\mathrm{I}_{\text {geo }}$ factor is classified in the following way: uncontaminated $\left(\mathrm{I}_{\text {geo }}<0\right)$; uncontaminated to moderately contaminated $\left(0<\mathrm{I}_{\text {geo }}<1\right)$; moderately contaminated $\left(1<\mathrm{I}_{\text {geo }}<2\right)$; moderately to strongly contaminated $\left(2<\mathrm{I}_{\text {geo }}<3\right)$; strongly contaminated $\left(3<\mathrm{I}_{\text {geo }}<4\right)$; strongly to extremely contaminated $\left(4<\mathrm{I}_{\text {geo }}<5\right)$ and extremely contaminated $\left(\mathrm{I}_{\text {geo }}>5\right)$.

Pollution load index (PLI) provides a simple and comparative means of assessing the level of potentially toxic element pollution of the sediment [54]. We calculated this index by using the following equation:

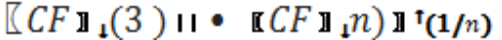

Although it is an ecological index, we assume that, based on its value, we can orientate ourselves to 
assess whether the peloid can be used for application to the skin.

For purpose of our work, we used natural geochemical background values for the Southern Adriatic, as Dolenec et al. have shown in their work [55]. Namely, in this paper the authors studied the concentrations and distributions of chemical elements in the surficial sea bottom sediments of the Adriatic Sea. According to these authors, the highest concentrations of most trace elements $(\mathrm{Be}, \mathrm{Co}, \mathrm{Cu}, \mathrm{Cr}, \mathrm{Ni}, \mathrm{Sc}, \mathrm{Th}, \mathrm{V}, \mathrm{Zr})$ are found in the southern Adriatic. Sediments of this area also exhibit high concentrations of $\mathrm{As}, \mathrm{La}, \mathrm{Hg}$, $\mathrm{Pb}$ and $\mathrm{Zn}$. Such potentially toxic element content is in some way expected due to the fact that heavy mineral accumulations such as chromite, titanomagnetite, ilmenite and rutile are found in the offshore sands of the southern Montenegro.

Table V

Medium, minimum and maximum concentrations of chemical elements in surficial sediments from the Southern

\begin{tabular}{|c|c|c|c|c|c|c|c|c|c|c|c|c|c|}
\hline $\begin{array}{c}\text { Element } \\
\text { Units }\end{array}$ & $\begin{array}{l}\text { Al } \\
\%\end{array}$ & $\begin{array}{c}\mathrm{Ca} \\
\% \\
\end{array}$ & $\begin{array}{c}\mathrm{Fe} \\
\%\end{array}$ & $\begin{array}{l}\mathrm{Ti} \\
\%\end{array}$ & $\begin{array}{l}\mathrm{K} \\
\%\end{array}$ & $\begin{array}{c}\mathrm{Mg} \\
\%\end{array}$ & $\begin{array}{l}\mathrm{P} \\
\%\end{array}$ & $\begin{array}{c}\text { Ba } \\
\text { ppm }\end{array}$ & $\begin{array}{c}\text { Mn } \\
\text { ppm }\end{array}$ & $\begin{array}{c}\mathrm{Sr} \\
\mathrm{ppm}\end{array}$ & $\begin{array}{c}\text { Ag } \\
\text { ppm }\end{array}$ & $\begin{array}{c}\text { As } \\
\text { ppm }\end{array}$ & $\begin{array}{c}\text { Be } \\
\text { ppm }\end{array}$ \\
\hline Mean & 5.13 & 10.25 & 2.96 & 0.24 & 1.61 & 2.3 & 0.05 & 237 & 1079 & 453 & 0.9 & 9.1 & 2.2 \\
\hline Min. & 3.96 & 6.33 & 2.04 & 0.19 & 1.12 & 1.79 & 0.04 & 153 & 572 & 290 & 0.5 & 1.0 & 1.6 \\
\hline Max. & 6.31 & 14.5 & 4.18 & 0.31 & 2.01 & 3.1 & 0.07 & 336 & 2050 & 664 & 1.3 & 19 & 2.7 \\
\hline $\begin{array}{c}\text { Element } \\
\text { Units }\end{array}$ & $\begin{array}{c}\text { Co } \\
\text { ppm }\end{array}$ & $\begin{array}{c}\mathrm{Cr} \\
\mathrm{ppm}\end{array}$ & $\begin{array}{c}\mathrm{Cu} \\
\text { ppm }\end{array}$ & $\begin{array}{c}\text { Hg } \\
\text { ppm }\end{array}$ & $\begin{array}{c}\text { La } \\
\text { ppm }\end{array}$ & $\begin{array}{c}\mathbf{N i} \\
\text { ppm }\end{array}$ & $\begin{array}{c}\mathrm{Pb} \\
\mathrm{ppm}\end{array}$ & $\begin{array}{c}\text { Sc } \\
\text { Ppm }\end{array}$ & $\begin{array}{c}\text { Th } \\
\text { ppm }\end{array}$ & $\begin{array}{c}\mathrm{U} \\
\mathbf{p p m}\end{array}$ & $\begin{array}{c}\mathrm{V} \\
\mathbf{p p m}\end{array}$ & $\begin{array}{c}\mathrm{Zn} \\
\mathrm{ppm}\end{array}$ & $\begin{array}{c}\mathrm{Zr} \\
\mathbf{p p m}\end{array}$ \\
\hline Mean & 18 & 110 & 34.7 & 0.133 & 25.8 & 128 & 11 & 11.1 & 7.4 & 2 & 102 & 76 & 46.1 \\
\hline Min. & 10 & 53 & 21.8 & 0.069 & 22.3 & 49 & 5 & 7.4 & 6.1 & 1.5 & 76 & 58 & 27.3 \\
\hline Max. & 25 & 246 & 44.9 & 0.419 & 28.8 & 264 & 18 & 15.9 & 8.2 & 3 & 142 & 101 & 53.9 \\
\hline
\end{tabular}

Table $\mathrm{V}$ shows medium, minimum and maximum concentrations of chemical elements in surficial sediments from the Southern Adriatic.
Based upon the given formulas and the data from the Tables I and V, we first calculated the Contamination factor for most of the determined elements and the results are shown in Table VI.

Table VI

Contamination factor for most of the determined elements in the Igalo peloid

\begin{tabular}{|c|c|l|}
\hline Element & Contamination factor & Description of peloid according to CF \\
\hline $\mathrm{Ti}$ & 3.33 & Considerable contamination \\
\hline $\mathrm{Fe}$ & 1.39 & Moderate contamination \\
\hline $\mathrm{Al}$ & 1.31 & Moderate contamination \\
\hline $\mathrm{Ca}$ & 0.53 & Low contamination \\
\hline $\mathrm{Ba}$ & 0.83 & Low contamination \\
\hline $\mathrm{Sr}$ & 0.34 & Low contamination \\
\hline $\mathrm{K}$ & 1.12 & Moderate contamination \\
\hline $\mathrm{Mg}$ & 0.91 & Low contamination \\
\hline $\mathrm{As}$ & 0.62 & Low contamination \\
\hline $\mathrm{Zr}$ & 1.04 & Moderate contamination \\
\hline Element & Contamination factor & Description of peloid according to CF \\
\hline $\mathrm{V}$ & 0.91 & Low contamination \\
\hline $\mathrm{Cr}$ & 1.84 & Moderate contamination \\
\hline $\mathrm{Mn}$ & 0.42 & Low contamination \\
\hline $\mathrm{Co}$ & 0.87 & Low contamination \\
\hline $\mathrm{Ni}$ & 1.08 & Moderate contamination \\
\hline $\mathrm{Cu}$ & 1.49 & Moderate contamination \\
\hline $\mathrm{Zn}$ & 1.03 & Moderate contamination \\
\hline $\mathrm{Hg}$ & 0.0008 & Low contamination \\
\hline $\mathrm{Be}$ & 0.41 & Low contamination \\
\hline $\mathrm{La}$ & 1.08 & Moderate contamination \\
\hline $\mathrm{Sc}$ & 1.32 & Moderate contamination \\
\hline $\mathrm{P}$ & 1.36 & Moderate contamination \\
\hline & & \\
\hline
\end{tabular}


Index of geoaccumulation for most of the determined elements in the Igalo peloid

\begin{tabular}{|c|c|l|}
\hline Element & Index of geoaccumulation & \multicolumn{1}{|c|}{ Description of peloid according to Igeo } \\
\hline $\mathrm{Ti}$ & 1.15 & Uncontaminated to moderately contaminated \\
\hline $\mathrm{Fe}$ & -0.12 & Uncontaminated \\
\hline $\mathrm{Al}$ & -0.20 & Uncontaminated \\
\hline $\mathrm{Ca}$ & -1.64 & Uncontaminated \\
\hline $\mathrm{Ba}$ & -0.86 & Uncontaminated \\
\hline $\mathrm{Sr}$ & -2.16 & Uncontaminated \\
\hline $\mathrm{K}$ & -0.43 & Uncontaminated \\
\hline $\mathrm{Mg}$ & -0.72 & Uncontaminated \\
\hline $\mathrm{As}$ & -1.29 & Uncontaminated \\
\hline $\mathrm{Zr}$ & -0.53 & Uncontaminated \\
\hline $\mathrm{V}$ & -0.73 & Uncontaminated \\
\hline $\mathrm{Cr}$ & 0.29 & Uncontaminated to moderately contaminated \\
\hline $\mathrm{Mn}$ & -5.18 & Uncontaminated \\
\hline $\mathrm{Co}$ & -0.79 & Uncontaminated \\
\hline $\mathrm{Ni}$ & -0.47 & Uncontaminated \\
\hline $\mathrm{Cu}$ & -0.01 & Uncontaminated \\
\hline $\mathrm{Zn}$ & -0.54 & Uncontaminated \\
\hline $\mathrm{Hg}$ & -10.87 & Uncontaminated \\
\hline $\mathrm{Be}$ & -1.88 & Uncontaminated \\
\hline $\mathrm{La}$ & -0.47 & Uncontaminated \\
\hline $\mathrm{Sc}$ & -0.19 & Uncontaminated \\
\hline $\mathrm{P}$ & -0.14 & Uncontaminated \\
\hline
\end{tabular}

Subsequently, we determined the Index of geoaccumulation $\left(\mathrm{I}_{\mathrm{geo}}\right)$ and the results are shown in Table VII.

\section{$\mathrm{PLI}=\sqrt[13]{\mathrm{CF}(\mathrm{As}) \cdot \mathrm{CF}(\mathrm{Zr}) \cdot \mathrm{CF}(\mathrm{Cr}) \cdot \mathrm{CF}(\mathrm{Mn}) \cdot \mathrm{CF}(\mathrm{Fe}) \cdot \mathrm{CF}(\mathrm{Co}) \cdot \mathrm{CF}(\mathrm{Ni}) \cdot \mathrm{CF}(\mathrm{Cu}) \cdot \mathrm{CF}(\mathrm{Zn}) \cdot \mathrm{CF}(\mathrm{Hg}) \cdot \mathrm{CF}(\mathrm{V}) \cdot \mathrm{CF}(\mathrm{Ti}) \cdot \mathrm{CF}(\mathrm{La})}=$}

And at the end, we calculated the Pollution load index (PLI) for potentially toxic elements:
The obtained value means that there is no potentially toxic element pollution in the sediment.

Long-term application of peloid therapy in both domestic and foreign users of balneotherapy in Igalo institute did not show any side effects or side effects on the skin. We consider that the toxicity of even heavy metals found at lower concentrations in the peloid cannot be expressed in a relatively short period of peeling on the skin. For the time being, there are no publications confirming the toxic metal concentration and the exposure time needed to allow the peloid to exhibit toxic effects.

\section{Conclusions}

In this paper, we examined the physico-chemical characteristics of the Igalo peloid. This is the first study of this type in Montenegro. The components of this natural resource have biological activity which requires further research both in vitro and in vivo, all for the sake of adequate scientifically validation of the same. Also, since the presence of potentially toxic elements and their concentration are very important parameters of the state of the environment and indicators of its pollution, on the basis of the measured values we calculated three quantitative parameters that shown that there is no potentially toxic element pollution in the sediment or the area from which the sampling was carried out.

Our future work will be focused on examining the presence of organic substances (fatty acids, carbohydrates, aminoacids and proteins), their quantity and nature, as well as the monitoring of possible side effects that the peloid could exhibit during the application.

\section{Conflict of interest}

The authors declare no conflict of interest.

\section{References}

1. Veniale F, Better A, Jobstraibiyer P, Setti M, Thermal muds: perspectives of innovations. Appl Clay Sci., 2007; 36(1-3): 141-147.

2. Lippard SJ, Berg JM, Principles of Bioinorganic chemistry, USA, 1994.

3. Grguric - Sipka S, Chemistry of bioelements, (edition in Serbian). Faculty for Chemistry, Belgrade, 2014.

4. James M, Lord, MP, McMillan chemical and physical data, London, 1992.

5. Gomez MI. Carretero M, Pozo F. Maraver P, Cantista P, Armijo F, Legido JL, Teixeira F, Rautureau M, Delgado R, Peloids and pelotherapy: historical evolution, classification and glossary. Appl Clay Sci., 2013; 75-76: 28-38. 
FARMACIA, 2020, Vol. 68, 3

6. Baschini M, Piovano E, Lopez-Galidno A, Dietrich D, Setti M, Muds and salts from Laguna Mar Chiquita (or Mar de Ansenuza), Cordoba, Argentina: natural materials with potential therapeutic uses. Anales de Hidrologia Medica, 2012; 5(2): 123-129.

7. Veniale F, Better A, Jobstraibiyer P, Setti M, Thermal muds: perspectives of innovations. Appl Clay Sci., 2007; 36(1-3): 141-147.

8. Okmen BM, Eroksuz R, Altan L, Aksoy MK, Efficacy of peloid therapy in patients with cronic lateral epicondylitis: a randomized, controlled, single blind study. Int J Biometeorol., 2017; 61(11): 1965-1972.

9. Antonelli M, Donelli D, Effects of balneotherapy and SPA therapy on levels of cortisol as a stress biomarker: a systematic review. Int J Biometeorol., 2018; 62: 913-924.

10. Okmen BM, Aksoy MK, Gunes A, Eroksu, R, Altan L, Effectiveness of peloid therapy in carpal tunnel syndrome: A randomized controlled single blind study. Int J Biometeorol., 2017; 61: 1403-1410.

11. Artymuk NV, Kira EF, Kondratieva TA, Intravaginal gel prepared from Dead Sea peloid for treating lutealphase defect. Int J Gynecol Obstet., 2009; 108: 72-73.

12. Komar D, Dolonec T, Dolonec M, Vrhovnik P, Lojen S, Belak SL, Kniewald G, Rogan Smuc N, Physicochemical and geochemical characterization of Makirina Bay peloid mud and its evaluation for potential use in balneotherapy (N. Dalmatia, Republic of Croatia). Ind J Tradit Knowl., 2015; 1(1): 5-12.

13. Joksimovic A, Djurovic M, Semenov A, Zonn I, Kostianoy A, The Boka Kotorska Bay Environment, Springer, Germany, 2017.

14. Khlaifat $\mathrm{O}, \mathrm{Al}-\mathrm{Khashman} \mathrm{H}$, Qutob $\mathrm{H}$, Physical and chemical characterization of Dead Sea mud. Mater Charact., 2010; 61: 564-568.

15. Summa $V$, Tateo $F$, The use of pelitic raw materials in thermal centers mineralogy, geochemistry, grain size and leaching tests. Examples from the Lucania area (southern Italy). Appl Clay Sci., 1998; 12(5): 403-417.

16. Carretero MI, Pozo M, Martin-Rubi JA, Pozo E, Maraver F, Mobility of elements in interaction between artificial sweat and peloids used in Spanish SPAs. Appl Clay Sci., 2010; 48(3): 506-515.

17. Frausto da Silva JJR, Williams RJP, The biological chemistry of the elements. Clarendon Press, Oxford, 1991.

18. Emsley J, Natures building blocks, Oxford University press, 2001, (edition in Croatian, "Izvori" Zagreb, Croatia, 2005).

19. Ragsdale SW, Metals and their scaffolds to promote difficult enzymatic reactions. Chem Rev., 2006; 106(8): 3317-3337.

20. Urban P, Health effects of metals. Metals and Neurotoxicity, 2009, 57.

21. Kuhn NJ, Ward S, Leong WS, Manganese in Golgi vesicle enzymes. Eur J Biochem., 1991; 195: 243-250.

22. Parat MO, Richard MJ, Leccia MT, Amblard P, Favier A, Beani JC, Does manganese protect cultured human skin fibroblasts against oxidative injury by UVA, dithranol and hydrogen peroxide?. Free Rad Res., 1995; 23: 339-351.

23. Vincent JB, The biochemistry of chromium. J Nutr., 2000; 130: 715-718.
24. Cefalu WT, Hu FB, Role of chromium in human health and in diabetes. Diabetes Care, 2004; 27(11): 2741-2751.

25. Zhang J, Li X, Chromium pollution of soil and water in Jinzhou. J Chin Prevent Med., 1987; 21(5): 262-264.

26. Nickel. Geneva, World Health Organization, 1991 (Environmental Health Criteria, No.108).

27. Sunderman FW, Hopfer SM, Sweeney KR, Marcus $\mathrm{AH}$, Most BM, Creason J, Nickel absorption and kinetics in human volunteers. Proceed Soc Experim Biol Med., 1989; 191(1): 5-11.

28. Ragsdale, SW, Nickel biochemistry. Curr Opin Chem Biol., 1998; 2(2): 208-215.

29. Crans DC, Smee JJ, Gaidamauskas E, Yang L, The chemistry and biochemistry of vanadium and the biological activities exerted by vanadium compounds. Chem Rev., 2004; 104(2): 849-902.

30. Auld DS, Zink coordination sphere in biochemical zink sites. Biometals, 2001; 14: 271-313.

31. Jackson MJ, Physiology of zinc: General aspects. In Mills CF. Zinc in Human Biology. Berlin/Heidelberg, Germany; New York, NY, USA: Springer; 1989; 1-14.

32. Tierney EP, Badger J, Etiology and pathogenesis of necrolytic migratory erythema: Review of the literature. MedGenMed., 2004; 6(3): 4.

33. Vannucchi H, Favaro RM, Cunha DF, Marchini, JS, Assessment of zinc nutritional status of pellagra. Alcohol Alcohol., 1995; 30: 297-302.

34. Lagier P, Bimar P, Seriat-Gautier S, Dejode JM, Brunt T, Bimar J, Zinc and biotin deficiency during prolonged parenteral nutrition in the infant. Presse Med., 1987; 16: 1795-1797.

35. Bhat YJ, Manzoor S, Khan AR, Qayoom S, Trace element levels in alopecia areata. Ind J Dermatol Venerol Leprol., 2009; 75: 29-31.

36. Kim JE, Yoo SR, Jeong MG, Ko JY, Ro YS, Hair zinc levels and the efficacy of oral zinc supplementation. Acta Derm Venereol., 2014; 94: 558-562.

37. Saglam K, Serce AF, Yilmaz MI, Bulucu F, Aydin A, Akay C, Sayal A, Trace elements and antioxidant enzymes in Behcet's disease. Rheumatol Int., 2002; 22: 93-96.

38. Kogan S, Sood A, Granick MS, Zinc and Wound Healing: A Review of Zinc Physiology and Clinical Applications. Wounds, 2017; 29(4) 102-106.

39. Kobayashi M, Shimizu S, Cobalt proteins. Eur J Biochem., 1999; 261(1): 1-9.

40. Brondino CD, Romao MJ, Moura I, Moura JG, Molybdenum and tungsten enzymes: the xanthine oxidase family. Curr Opin Chem Biol., 2006; 10: 109-114.

41. Williams RJP, The evolution of calcium biochemistry. Biochim Biophys Acta, 2006; 1763(11): 1139-1146.

42. Fairley J, Calcium metabolism and the pathogenesis of dermatologic disease. Seminars in Dermatology, 1991; 10(3): 225-231.

43. Lansdown $\mathrm{AB}$, Calcium: a potential central regulator in wound healing in the skin. Wound Repair Regen., 2002; 10: 271-285.

44. Collman JP, Boulatov R, Sunderland CJ, Fu L, Functional analogues of cytochrome $\mathrm{C}$ oxidase, myoglobin and hemoglobin. Chem Rev., 2004; 104(2): 561-588. 
45. Khanbhai MLS, Wright JA, Hurel S, Richards T, Anaemia, inflammation, renal function, and the diabetic foot: what are the relationships?. Diabet Foot J., 2012; 15(4): 150-158.

46. Wright JA, Richards T, Srai SKS, The role of iron in the skin and cutaneous wound healing. Front Pharmacol., 2014; 5: 156

47. Denda M, Hosoi J, Asida Y, Visual imaging of ion distribution in human epidermis. Biochem Biophys Res Commun., 2000; 27(1): 134-137.

48. Cowan JA, Structural and catalytic chemistry of magnesium-dependent enzymes. Biometals, 2002; 15: 225-235.

49. Gouax E, McKinnon R, Principles of selective ion transport in channels and pumps. Science, 2005; 310(5753): 1461-1465.

50. Araújo LA, Addor F, Campos PM, Use of silicon for skin and hair care: an approach of chemical forms available and efficacy. An Bras Dermatol., 2016; 91(3): 331-335.
51. Reffitt DM, Onjrchebtr A, Cheung HFJ, Evans BAJ, Thompson RPH, Powell JJ, Hampson GN, Orthosilicic acid stimulates collagen type 1 synthesis and osteoblastic differentiation in human osteoblast-like cells in vitro. Bone, 2003; 32(2): 127-135.

52. Hakanson L, Ecological risk index of aquatic pollution control - a sedimentological approach. Water Res., 1980; 14(8): 975-1001.

53. Müller G, Index of Geoaccumulation in sediments of the Rhine River. Geo Journal, 1969; 2: 108-118.

54. Tomlinson DL, Wilson JG, Harris CR, Jeffrey DW, Problems in the assessment of heavy metals levels in estuaries and the formation of a pollution index. Helgolander Meeresun., 1980; 33: 566-575.

55. Dolenec T, Faganeli J, Pirc S, Major, minor and trace elements in surficial sediments from the open Adriatic Sea: a regional geochemical study. Geol Croat., 1998; 51: 59-73. 